\title{
A new species of isopod (Isopoda: Flabellifera: Sphaeromatidae) from Cuba, with an identification key for the species of Paraimene
}

\author{
Una especie nueva de isópodo (Isopoda: Flabellifera: Sphaeromatidae) de Cuba, con una clave \\ de identificación para las especies de Paraimene
}

\author{
Manuel Ortiz ${ }^{凶}$, Ignacio Winfield and Sergio Cházaro-Olvera \\ Laboratorio de Crustáceos. Facultad de Estudios Superiores Iztacala, Universidad Nacional Autónoma de México. Av. De los Barrios 1, Los Reyes de \\ Iztacala, 54090 Tlalnepantla, Estado de México, México. \\ 凶ortiztouzet@yahoo.com
}

\begin{abstract}
A new species of isopod crustacean belonging to the genus Paraimene (Flabellifera, Sphaeromatidae) is described. The new species was collected from Cojimar Bay, La Habana Province, Cuba. Paraimene danieli new species differs from all other known species of the genus by the following characters: pereonites 2-3 smooth, pereonites 5-6 carinate, pereonite 7 and pleonite 1 raised at middle point, lacinia mobilis with 3 cusps. An identification key to species of Paraimene is provided.
\end{abstract}

Key words: Isopoda, new species, coast, Cuba.

Resumen. Se describe una especie nueva de isópodo perteneciente al género Paraimene (Isopoda, Flabellifera, Sphaeromatidae). La especie nueva fue colectada de la Bahía de Cojimar, Provincia La Habana, Cuba. Paraimene danieli especie nueva difiere de las especies conocidas del género por los siguientes caracteres: lacinia mobilis con 3 cúspides; pereonites 2-3 lisos, pereonites 5-6 carinados, pereonite 7 y pleonite 1 elevados medialmente. Se presenta una clave de identificación para las especies de Paraimene.

Palabras clave: Isopoda, especie nueva, costa, Cuba.

\section{Introduction}

The genus Paraimene was erected to receive $P$. tuberculata Javed and Ahmed, 1988 from the rocky intertidal of Cape Monze, Pakistan (Javed and Ahmed, 1988). Since then, 3 new species have been added to the genus: Paraimene charlesae Kensley and Schotte, 1994, from Dominica; P. ibarzabalae Kensley, Ortiz and Schotte, 1997, and P. tumulus Kensley, Ortiz and Schotte, 1997, both from the Cuban Archipelago.

This paper contributes with the description of the fifth known species of Paraimene and the third from the Cuban Archipelago.

\section{Materials and methods}

The material examined was collected by hand rasping with a spatula the surface of a concrete pier directly into a plastic bag, at a $0.2 \mathrm{~m}$ depth. The specimens were fixed with formalin solution and transferred to $70 \%$ ethanol. Isopods were sorted and examined using a stereo microscope Karl Zeiss, Jenaval model. The figures were made with

Recibido: 08septiembre 2011; aceptado: 25 abril 2012 the aid of a camera lucida. Description and terminology used herein follows Kensley et al. (1997) all measurement provided correspond to total length.

\section{Description}

Order Isopoda Latreille, 1817

Suborder Flabellifera Sars, 1882

Family Sphaeromatidae H. Milne Edwards, 1840

Paraimene danieli n. sp. (Figs. 1-4)

Diagnosis. Pereonites 5 and 6 each with a tuberculate transverse carina. Pereonite 7 with 2 subcentral tubercles. Posterior margin of pleon with 2 pairs of rounded tubercles of which one is larger than the other. Pleotelson of male basally inflated with one row of 4 small basally placed, rounded protuberances, and another row distally bearing 2 very small lateral protuberances and 2 elongate inner and parallel bosses, posteriorly. Pleopod 2 appendix masculine inserted basally, 1/3 longer than endopod.

Body length, 1.8 times greatest width. Pereonites 1-6 width increasing posteriorly. Dorsal integument surface smooth with scattered setae. Rostral point not visible from above (Figs. 1A, D). Epistome broadly rounded, arms 

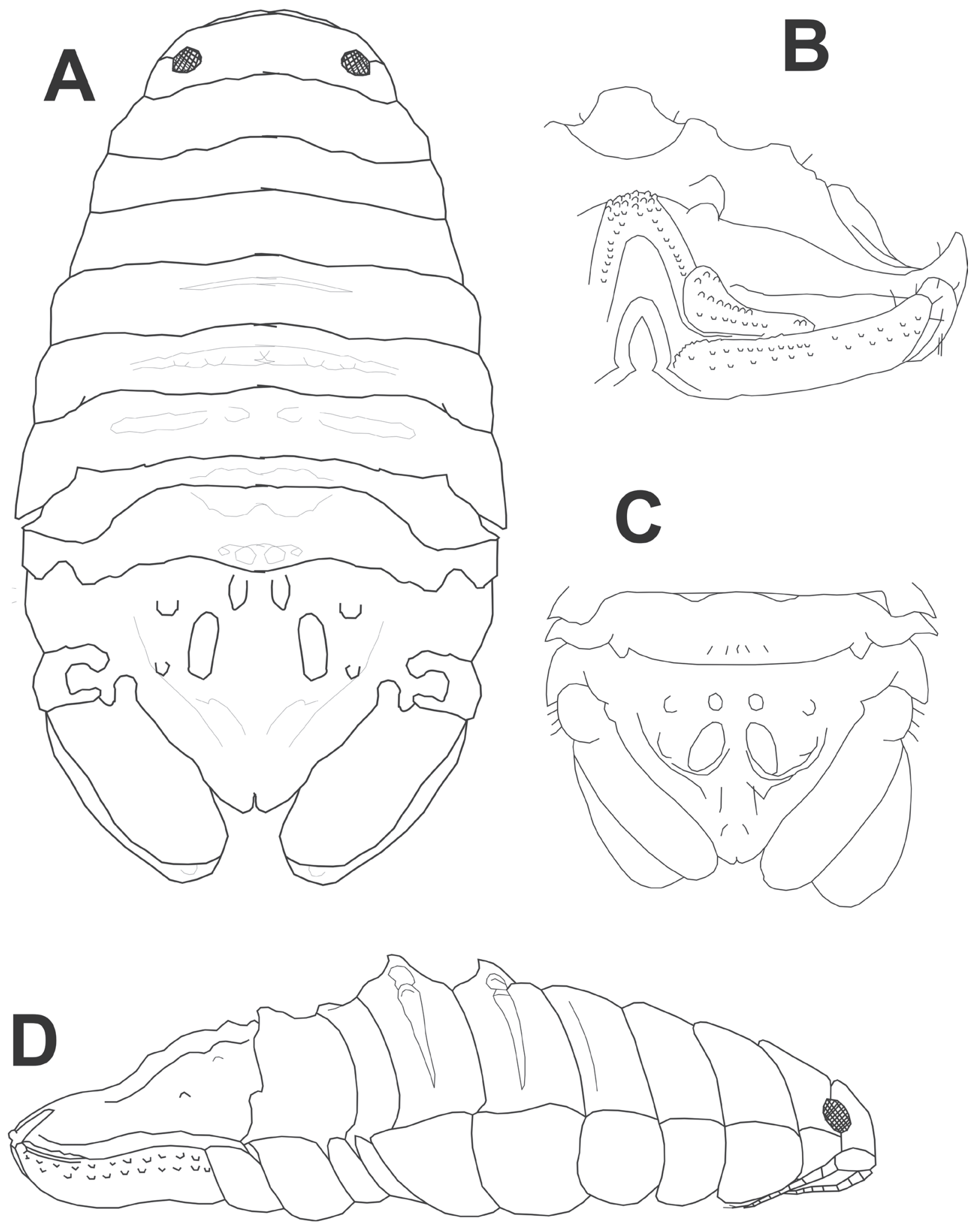

Figure 1. Paraimene danieli new species. A, dorsal view of male; B, posterior view of right half of male pleotelson; C, pleotelson of female; D, lateral view of male. 


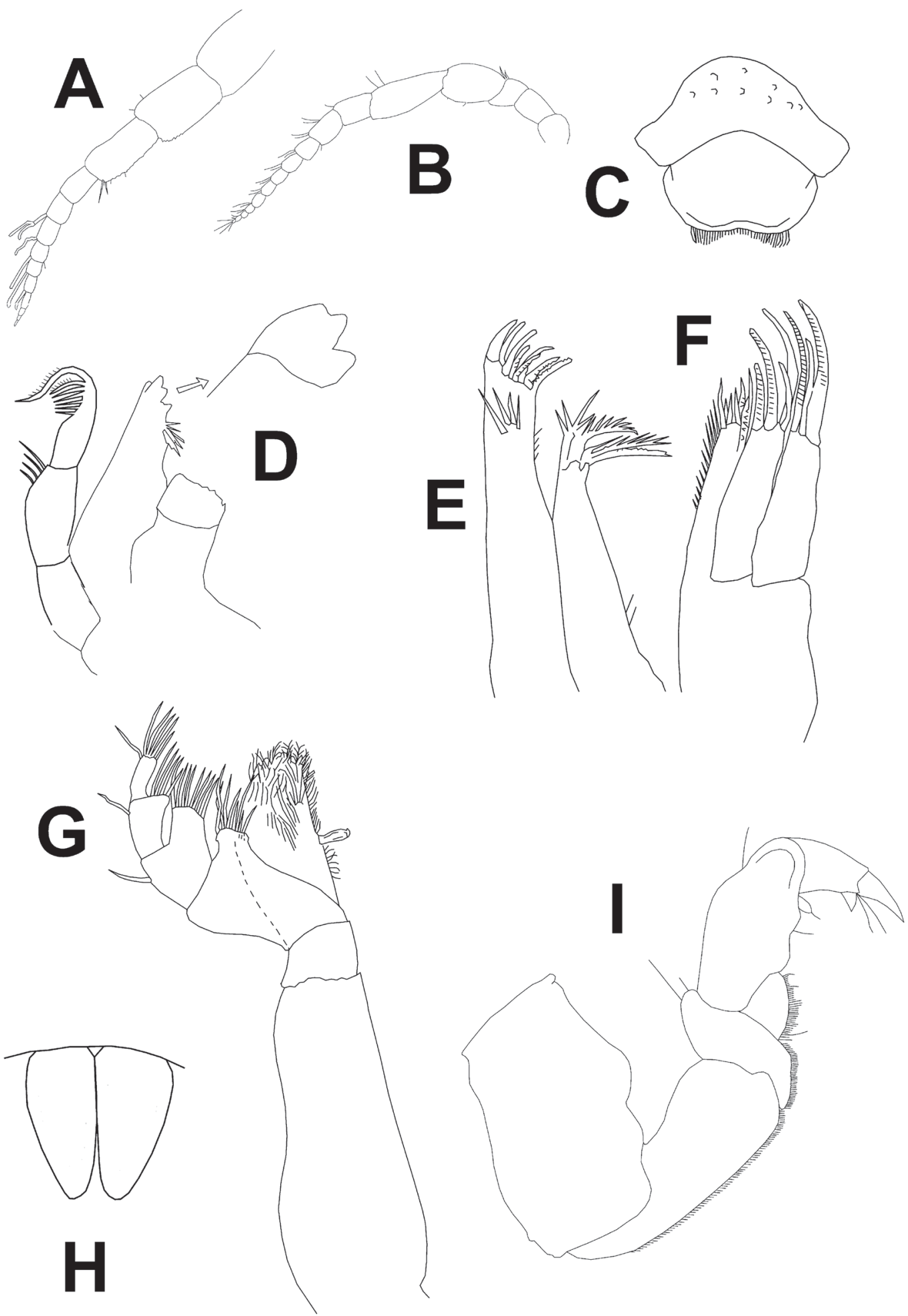

Figure 2. Paraimene danieli new species. Male: A, antennula; B, antenna; C, frontal lamina and labium; D, mandible; E, maxilla 1; F, maxilla 2; G, maxilliped; H, penes; I, pereopod 1 . 

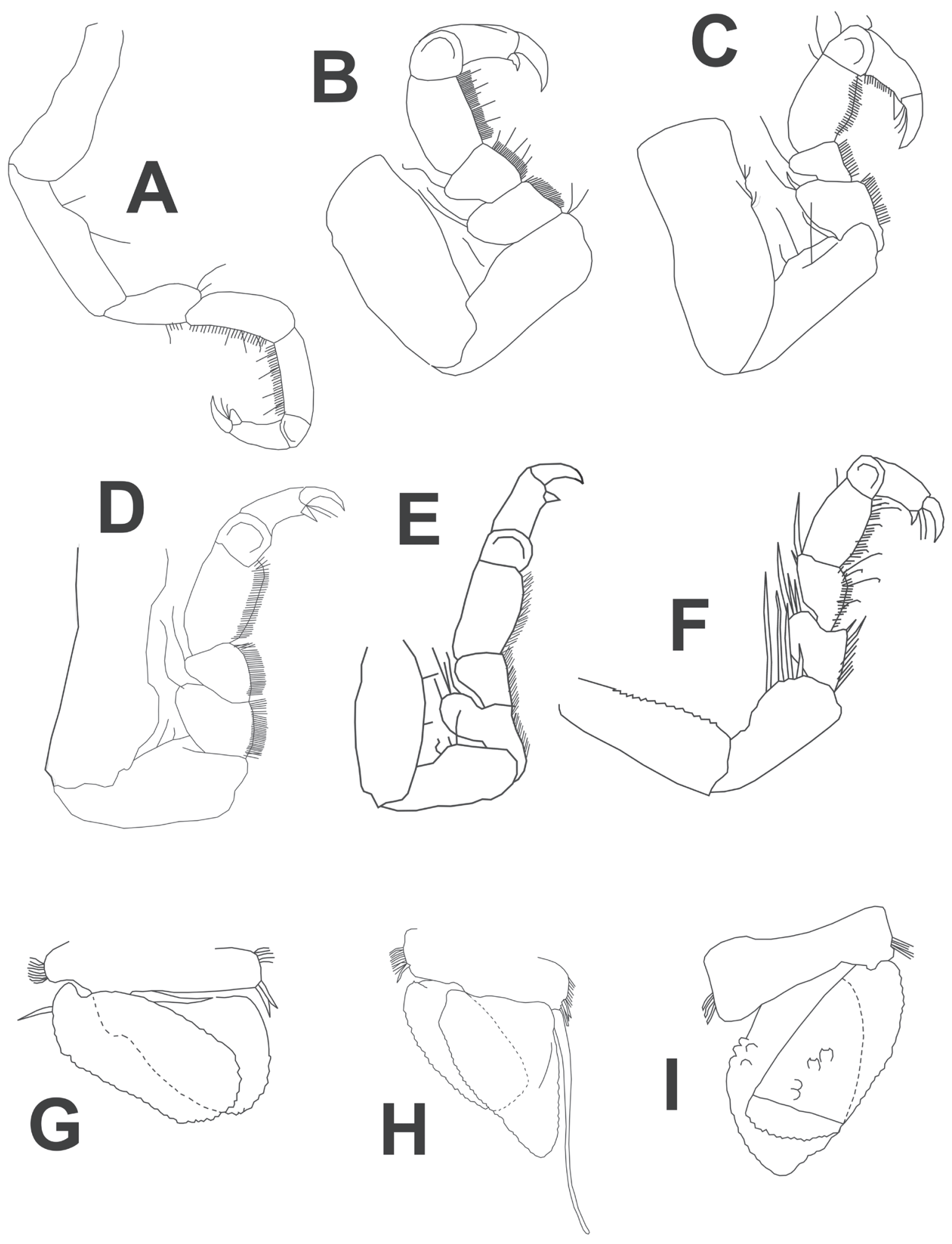

Figure 3. Paraimene danieli new species. Male: A, pereopod 2; B, pereopod 3; C, pereopod 4; D, pereopod 5; E, pereopod 6; F, pereopod 7; G, pleopod 1; H, pleopod 2; I, pleopod 3. 

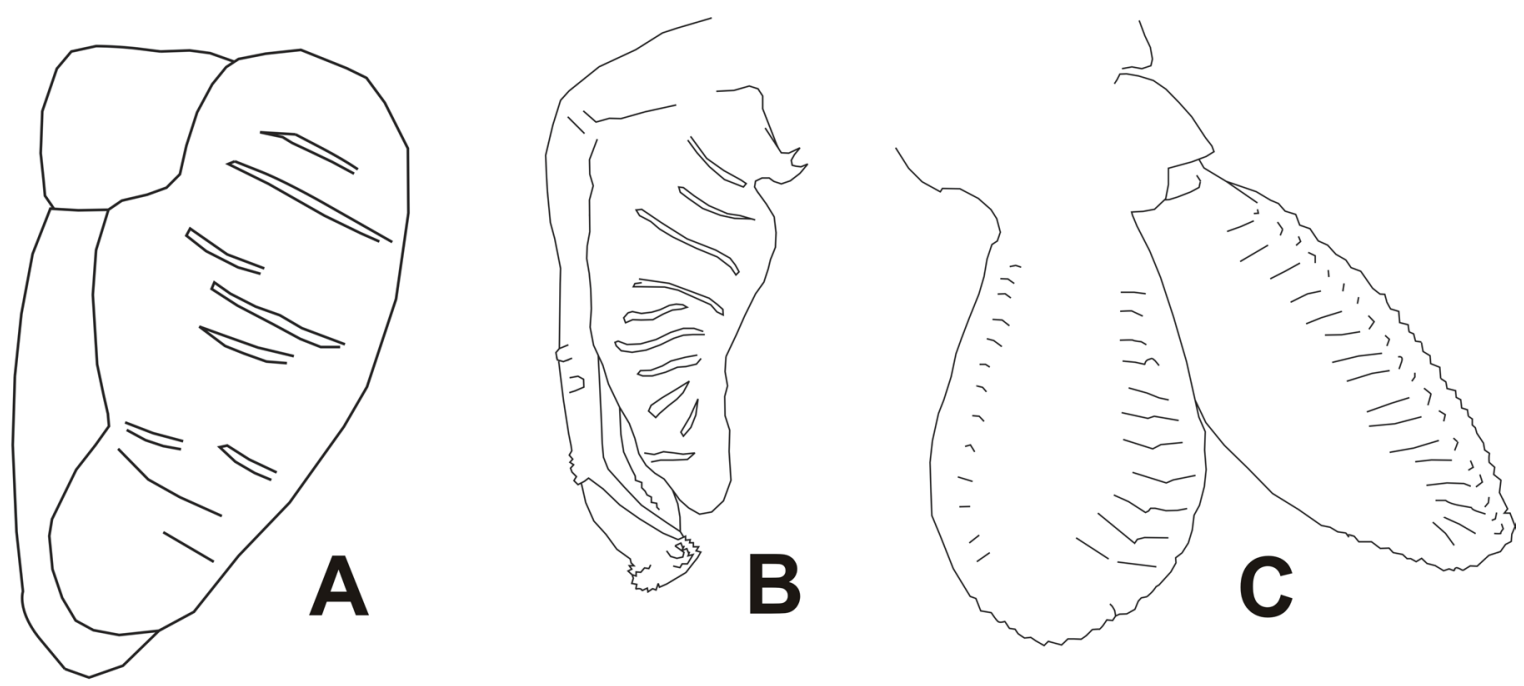

\section{Scales}

$0.5 \mathrm{~mm}$ Dorsal and lateral view of body

\section{$0.1 \mathrm{~mm}$ Bucal pieces}

$0.5 \mathrm{~mm}$ Antennae, uropods, penes, and pleotelson of female

$0.5 \mathrm{~mm}$ Pereopods and pleotelson of male

\section{$0.5 \mathrm{~mm} \quad$ Pleopods}

Figure 4. Paraimene danieli new species. Male: A, pleopod 4; B, pleopod 5; C, uropod.

barely extending over labrum (Fig. 2C). Lower margin of labrum fully setose laterally (Fig. 2C). Eyes large, dorsal lateral (Figs. 1A, D). Pereonites 1-3 smooth (Figs. 1A, D). Pereonite 7 shorter than 6 , overlapped by 6 (Fig. 1A). Pleotelson markedly domed; posterior half of pleotelson tapering to narrow apex in dorsal view. Edges of pleotelson forming a vertical slit when viewed posteriorly (Fig. 1B). Lateral margin of anterior pleotelson up-curved, concave submarginal area visible (Fig. 1B). Antennula with 3 peduncle articles subequal in length; flagellum with 10 articles, 2-9 bearing aesthetasc (Fig. 2A). Antenna slender; article 5 longer and slender than 4; flagellum with 11 articles, a pair of setae on articles 2-10 (Fig. 2B). Mandible bearing incisor and lacinia mobilis with 3 cusps; with a row of 4 fringed robust setae. Palp 3-articulated, article 2 with 4 fringed setae on distolateral margin; article 3 bearing 5 fringed setae distolaterally (Fig. 2D). Maxilla 1 inner ramus shorter than outer, inner with 3 fringed distal setae; outer ramus with 8 blunt distal and 4 facial subdistal setae (Fig. 2E). Maxilla 2 inner ramus with 5 apical and 12 marginal subapical setae; medial lobes with 4 and outer with 3 (Fig. 2F). Maxilliped endite with 5 blunt and somewhat bifid distal robust seta, 3 tuffs of setae, and one coupling hook; palp 5-articulated; articles 2 to 5 with distomesial margin bearing 4 or more distal setae (Fig. 2G). Pereopods 1-7 with a posterodistal small robust seta, with long nails curving backward (Figs. 2I, 3A-F). Pereopods 3-7 with dense fringed setules covering posterior margin of merus, carpus and propodus (Figs. 3B-F). Pereopod 1 shorter and stouter than pereopod 2; with stout robust seta on posterodistal margin of propodus (Fig. 2I). Pereopod 2 slender; ischium with anterior margin somewhat swollen (Fig. 3A). Pereopods 
3-5 similar in shape (Figs. 3B-D). Pereopod 6 with strong anterior lobe on merus (Fig. 3E). Pereopod 7 with 4 long setae on anterior margin ischium, 3 on merus and one on carpus (Fig. 3F). Penes short, unfused but close together, distally rounded (Fig. 2H). Pleopod 1 with 2 coupling hooks on basis; a strong, robust seta on outer proximal margin of exopod (Fig. 3G). Pleopod 2 with 3 coupling hooks on basis; appendix masculina tapering, apex rounded (Fig. $3 \mathrm{H}$ ). Pleopod 3 with 3 coupling hooks on basis; exopod with a complete transverse distal suture; endopod with 5 small booses on inner margin; exopodite with 4 (Fig. 3I). Pleopod 4 membranous; exopod folded; endopod rounded distally (Fig. 4A). Pleopod 5 with both rami membranous, without setae; exopod with 3 spinulose booses (Fig. 4B). Uropod with endopod distally setose, a little upturned, mesial margin deeply grooved; exopod with distal and lateral margins densely crenulated and submarginal striated. Uropodal rami extending beyond apex of ramus by 1/7 of length (Figs. 1A, 4C). Female. Similar to male, smaller; pleon posterior margin without tubercles. Pleotelson similar to male, 2 inner bosses of distal row diverging backward (Fig. 1C). Color in live: almost black. Color in ethanol, dark brown with pigmentation somewhat variable in posterior part.

Taxonomic Summary

Material examined. Holotype: male; $4 \mathrm{~mm}$; 6 January 2011; pier on the back yard of the house placed at Real 127, Cojímar, Municipio Habana del Este, $16 \mathrm{~km}$ east from Havana Harbour, Cuba; hand-rasped material from concrete pier. Invertebrates Collection, Center for Marine
Research, University of Havana, Cuba, Nr. 253 Marinas, Universidad de La Habana. Type locality: coordinates 2309'54" N, 82॰17'38" W.

Paratypes: male, $3.9 \mathrm{~mm}$ : male, $3.5 \mathrm{~mm}$; male, $2.8 \mathrm{~mm}$; male, $3.3 \mathrm{~mm}$; male. $3 \mathrm{~mm}$; male, $3.1 \mathrm{~mm}$; male, $3.2 \mathrm{~mm}$ : male; $3.3 \mathrm{~mm}$; male, $3.2 \mathrm{~mm}$; male, $2.5 \mathrm{~mm}$; male, 2.1 $\mathrm{mm}$; female, $2.5 \mathrm{~mm}$; female, $2.1 \mathrm{~mm}$. All collected and deposited together with the holotype. Nr. 254.

Etymology. The species is dedicated to Daniel Enrique Ortiz, nephew grandson of the senior author, for his help in the field work when collecting the new species.

Remarks

According to Kensley et al. (1997) and Schotte et al. (2009), there are no records of the genus Paraimene for the entire Gulf of Mexico and P. danieli n. sp.; therefore, represents the first record for the Gulf of Mexico. Paraimene ibarzabalae and P. tumulus were collected from Punta Frances, Cayo Frances, Isla de la Juventud and Cayo Esquivel, all locaties out of the Gulf of Mexico.

Paraimene danieli $\mathrm{n}$. sp. differs from the 4 other known species by several characters (see Table 1). Most useful characters to separate the new species from the others are the ornamentation of the pleotelson and the presence of 9 of more articles on flagella of antennae. Even so, the former is easy distinguished from the 2 Cuban species $P$. ibarzabalae and $P$. tumulus, since the lacinia mobilis has 3 cusps, instead of 5 or 3 , as well as by the ornaments of the pleotelson. The number of flagellum articles on the antennula and antenna are also useful when separating these species (Table 1).

Table 1. Comparison among the males of the 5 known species in the genus Paraimene

\begin{tabular}{|c|c|c|c|c|c|}
\hline Characteristics & P. tuberculata & P. charlesae & P. ibarzabalae & P. tumulus & P. danieli n. $s p$. \\
\hline Pereon segments ornaments & $2-7$ & --None- & $5-6$ & -None-- & $5-7$ \\
\hline Pleotelson ornaments & $\begin{array}{l}2 \text { rounded; } \\
4 \text { elongate }\end{array}$ & 4 rounded & 8 rounded & $\begin{array}{l}4 \text { rounded; } \\
4 \text { elongate }\end{array}$ & $\begin{array}{l}6 \text { rounded; } \\
2 \text { elongate }\end{array}$ \\
\hline Rostral point (in dorsal view) & Barely visible & Not visible & Visible & Barely visible & Not visible \\
\hline Antennular flagelum & 6 articles & 7 articles & 7 articles & 7 articles & 10 articles \\
\hline Antennal flagelum & 8 articles & 10 articles & 8 articles & 11 articles & 11 articles \\
\hline Lacinia mobilis & 3 cusps & 2 cusps & 5 cusps & 2 cusps & 3 cusps \\
\hline Penes & Separate & $\begin{array}{c}\text { Stubby } \\
\text { (not illustrated) }\end{array}$ & Separated & $\begin{array}{l}\text { Unfused, stubby } \\
\text { (not illustrated) }\end{array}$ & Fully in contact \\
\hline $\begin{array}{l}\text { Appendix masculina on } \\
\text { pleopod } 2\end{array}$ & $\begin{array}{c}\text { extending } \\
\text { beyond apex of } \\
\text { ramus by } 1 / 3 \text { of } \\
\text { length }\end{array}$ & $\begin{array}{c}\text { extending } \\
\text { beyond apex of } \\
\text { ramus by } 1 / 2 \text { of } \\
\text { length }\end{array}$ & $\begin{array}{c}\text { extending } \\
\text { beyond apex of } \\
\text { ramus by } 1 / 6 \text { of } \\
\text { length }\end{array}$ & $\begin{array}{c}\text { extending } \\
\text { beyond apex of } \\
\text { ramus by } 1 / 3 \text { of } \\
\text { length }\end{array}$ & $\begin{array}{c}\text { extending } \\
\text { beyond apex of } \\
\text { ramus by } 1 / 3 \text { of } \\
\text { length }\end{array}$ \\
\hline $\begin{array}{l}\text { Fringed setae on mandible palp } \\
\text { article } 3\end{array}$ & 7 & 5 & 5 & 5 & 7 \\
\hline Type locality & Pakistan & Dominica & Cuba & Cuba & Cuba \\
\hline
\end{tabular}


Key to the species of the genus Paraimene (males).

Pereonal segments 1-3 ornamented P. tuberculata

- Pereonal segments 1-3 smooth .2

Pereonal segments 4-6 smooth .3

Pereonal segments 4-6 carinate .4

3- Pleotelson with a pair of rounded tubercles on each side . P. charlesae

- Pleotelson with 2 rounded tubercles above and 2 others elongate below on each side P. tumulus Pereonite 7 and pleonite 1 smooth; antennular and antennal flagella with 8 or less articles; pleotelson with 8 small tubercles; lacinia mobilis with 5 cusps P. ibarzabalae Pereonite 7 and pleonite 1 raised at middle point; antennular and antennal flagella with 9 or more articles; pleotelson with 6 elongate and 2 small tubercles; lacinia mobilis with 3 cusps P. danieli n. sp.

\section{Acknowledgments}

We gratefully acknowledge the funds obtained through grants from the PAPIME-UNAM PE207311 and PAPIITUNAM 229011 projects.

\section{Literature cited}

Javed, W. and R. Ahmed. 1988. Paraimene tuberculata, a new genus and species of Isopoda (Sphaeromatidae) from Karachi, Pakistan. Hydrobiologia 169:371-377.

Kensley, B., M. Ortiz and M. Schotte. 1997. New records of marine Isopods from Cuba (Crustacea, Peracarida). Proceeding of the Biological Society of Washington 110:74-98.

Schotte, M., J. C. Markham and G. D. F. Wilson. 2009. Isopoda. In Gulf of Mexico- Origin, Waters and Biota, volume 1, D. Felder and D. Camp (eds.). Texas A\&M University Press. Texas. p. 973-986. 